\title{
LOCALIZATION OF SENSITIVITY TO KANAMYCIN AND STREPTOMYCIN IN 30S RIBOSOMAL PROTEINS OF ESCHERICHIA COLI
}

\author{
Hiroshi Masukawa \\ Institute of Applied Microbiology, University of Tokyo, \\ Bunkyo-ku, Tokyo, Japan
}

(Received for publication September 25, 1969)

\begin{abstract}
The localization in ribosomes of sensitivity to kanamycin was investigated and compared with that to streptomycin, using ribosomes from a mutant of Escherichia coli resistant to both these antibiotics. It was demonstrated that the sensitivity to both antibiotics was located in the $30 \mathrm{~S}$ subunit. The $30 \mathrm{~S}$ subunit was fractionated into a $23 \mathrm{~S}$ core and split proteins 30 , and the $23 \mathrm{~S}$ core was split further into core proteins 30 and $16 \mathrm{~S}$ ribosomal RNA. It was found that the sensitivity to kanamycin as well as to streptomycin resided in proteins of the $23 \mathrm{~S}$ core. To identify the responsible component, $30 \mathrm{~S}$ ribosomal proteins from the parent strain and from a kanamycin-resistant mutant were labelled differently, and co-chromatographed through carboxymethylcellulose column. Only one component (P 10) was observed to appear inconsistently in the elution profile, and it was therefore assumed to be the component that determined the sensitivity to kanamycin. This assumption was confirmed by examining the inhibition by kanamycin in poly U-directed incorporation of phenylalanine with $30 \mathrm{~S}$ subunits reconstituted in different combinations between $\mathrm{P} 10$ and the other components from the two origins. This component and the component controlling sensitivity to streptomycin were identical. It was observed that the reconstituted ribosomes containing P 10 from either resistant mutant were resistant to both antibiotics, and P 10 protein in both mutants was altered.
\end{abstract}

Aminoglycosidic antibiotics inhibit protein synthesis in bacteria and the site of their action is located in ribosomes ${ }^{1,2}$. Mutants resistant to these antibiotics are a very helpful tool for elucidation of the precise site and the mechanism of action of the antibiotics. Especially extensive studies have been carried out for this purpose using streptomycin (SM)-resistant mutants ${ }^{3 \sim 10)}$. Recently, Ozaki, Mizushima and NomURA showed that one component of $30 \mathrm{~S}$ ribosomal proteins was altered in SMresistant mutants, and that this component was responsible for the resistance to SM in reconstitution experiment ${ }^{11}$. This result proved that mutation in the SM locus induces an alteration in the structure of a specific ribosomal protein to bring about resistance to SM.

Of the aminoglycosidic group, kanamycin (KM), SM, neomycin, paromomycin, gentamicin, hygromycin etc. have been observed to cause codon misreading ${ }^{12,13,14)}$. Kasugamycin and spectinomycin, however, exhibit no misreading ${ }^{15,16)}$. Although the mechanism of misreading is complicated ${ }^{12,17)}$, it seems that the deoxystreptamine or 
streptamine moiety of these antibiotics plays an important role ${ }^{18,19)}$. On the basis of chemical relationship, it can be expected that $\mathrm{KM}$ acts on ribosomes in a similar manner to SM. However, the resistance of microorganisms to the two antibiotics has a complicated correlation : i.e. some microorganisms show one-way cross-resistance, but others exhibit no significant cross-resistance ${ }^{20,21)}$. The location of KM resistance and SM resistance in the same ribosomal protein would, of course, be less predictable if the ribosomes were not cross-resistant.

It is therefore interesting to elucidate the mechanism of action of KM, comparing with that of SM. In the present publication, it is demonstrated that one component of $30 \mathrm{~S}$ ribosomal proteins is altered in $\mathrm{KM}$-resistant mutants, and that it is identical to the component determining sensitivity to SM.

\section{Materials}

Organisms: E. coli strain NIHJ, a laboratory-developed KM-resistant mutant and a SM-resistant one were kindly given by the National Institute of Health, Tokyo, Japan. The minimal growth-inhibitory concentrations of $\mathrm{KM}$ and SM were both $2 \mu \mathrm{g} / \mathrm{ml}$ against the parent strain, $1,000 \mu \mathrm{g} / \mathrm{ml}$ and $64 \mu \mathrm{g} / \mathrm{ml}$ against the $\mathrm{KM}$-resistant mutant, and $2 \mu \mathrm{g} / \mathrm{ml}$ and $3,000 \mu \mathrm{g} / \mathrm{ml}$ against the SM-resistant mutant, respectively. In polyphenylalanine synthesis with $70 \mathrm{~S}$ ribosomes from parent cell extract, percents inhibitions of $\mathrm{KM}$ and SM $\left(10^{-5} \mathrm{M}\right)$ were $59 \%$ and $46 \%$. Those of $\mathrm{KM}$ and $\mathrm{SM}$ were $0 \%$ and $25 \%$ against the $\mathrm{KM}-$ resistant ribosomes; and $42 \%$ and $2 \%$ against the SM-resistant ribosomes. Therefore, $\mathrm{KM}$-resistant mutant was resistant to $\mathrm{SM}$, but SM-resistant one was sensitive to KM. The tendency of one-way cross resistance was observed in the protein synthesis, as in the case of antibacterial activity.

Chemicals : ${ }^{14} \mathrm{C}-$ Phenylalanine $(297 \mathrm{mC} / \mathrm{mm}),{ }^{14} \mathrm{C}$-isoleucine $(79.2 \mathrm{mC} / \mathrm{mM}),{ }^{14} \mathrm{C}$-lysine $(198 \mathrm{mC} / \mathrm{mm})$ and ${ }^{3} \mathrm{H}-$ lysine $(256 \mathrm{mC} / \mathrm{mM})$ were purchased from Daiichi Pure Chemicals Co. Ltd., Tokyo, Japan. Polyuridylic acid and creatine phosphate were obtained from Calbiochem, Los Angeles, California, U. S. A.; guanosine-5'-triphosphate (GTP) and creatine phosphokinase from C. F. Boehringer \& Soehne GmbH. Mannheim, Germany ; adenosine.5'-triphosphate (ATP) from Daiichi Pure Chemicals Co. Ltd.; cesium chloride from E. Merck AG Darmstadt, Germany. Carboxymethylcellulose (CMC, $0.77 \mathrm{meq} / \mathrm{g}$ ) was the product of Brown Co. Ltd. Soluble RNA was prepared by phenol extraction from the $105,000 \times g$ supernatant fraction of $E$. coli NIHJ extracts ${ }^{22)}$.

\section{Methods}

Preparation of Ribosomes and Ribosomal Subunits

The cells of $E$. coli NIHJ strain harvested at the late logarithmic phase of growth were ground with sea sand and extracted with standard buffer solution containing $\mathrm{Mg}$ acetate $10 \mathrm{~mm}, \mathrm{NH}_{4} \mathrm{Cl} 50 \mathrm{~mm}, 2$-mercaptoethanol $6 \mathrm{~mm}$, and Tris- $\mathrm{HCl} 10 \mathrm{~mm} \mathrm{pH} \mathrm{7.6.}$ The crude extract was centrifuged at $105,000 \times \mathrm{g}$ for 2 hours to obtain ribosomes.

The preparation of $50 \mathrm{~S}$ and $30 \mathrm{~S}$ ribosomes, and $23 \mathrm{~S}$ core and split proteins 30 (SP30), and their reconstitution principally followed the mdthod of Hosokawa et al. ${ }^{23)}$ and Staenelin and Meselson ${ }^{24)}$.

Ribosomes were dissociated into $30 \mathrm{~S}$ and $50 \mathrm{~S}$ subunits by dialysis against standard buffer solution in which the concentration of $\mathrm{Mg}$ acetate was lowered to $0.1 \mathrm{~mm}$. The suspension was layered on a sucrose gradient $(5 \sim 20 \%)$ and centrifuged in an SW 25 rotor (Beckmann) at $21,000 \mathrm{rpm}$ for 14 hours at $4^{\circ} \mathrm{C}$.

The $30 \mathrm{~S}$ subunits were further dissociated into $23 \mathrm{~S}$ core and SP 30 by centrifugation in $5.2 \mathrm{M}$ cesium chloride solution in an SW 40 rotor (Beckmann) at $36,000 \mathrm{rpm}$ for 38 hours. 
The solution contained $40 \mathrm{mM} \mathrm{Mg}$ acetate and $2 \times 10^{-4} \mathrm{M} \mathrm{EDTA}^{25)}$. SP 30 was recovered from the top of the gradient, and $23 \mathrm{~S}$ core was recovered from approximately at the middle of the gradient.

The preparation of $16 \mathrm{~S}$ ribosomal RNA and core proteins 30 (CP 30) from $23 \mathrm{~S}$ core particles followed the method of $\mathrm{TRAUB}_{\mathrm{R}}$ and NomURA ${ }^{10)}$. The $16 \mathrm{~S}$ ribosomal RNA was prepared from the $23 \mathrm{~S}$ core by treatment with phenol. CP 30 from the $23 \mathrm{~S}$ core was prepared by the treatment with a solution consisted of $6 \mathrm{M}$ urea, $2 \mathrm{M} \mathrm{LiCl}$ and $2.5 \mathrm{mM}$ EDTA.

\section{CMC Column Chromatography of $30 \mathrm{~S}$ Ribosomal Proteins}

The $30 \mathrm{~S}$ ribosomal subunits prepared by the afore-mentioned procedure were dialysed against $2 \mathrm{M} \mathrm{NH}_{4} \mathrm{Cl}$, and then against $6 \mathrm{M}$ urea containing $12 \mathrm{~mm} 2$-mercaptoethanol. Ribosomal RNA in the sample was digested with $10 \mu \mathrm{g} / \mathrm{ml}$ each of pancreatic and $T_{1}$ RNases at $37^{\circ} \mathrm{C}$ for 20 minutes. The dissociated ribosomal proteins were applied on a CMC column, and eluted with a linear sodium acetate gradient $(0.05 \sim 0.5 \mathrm{M})$ in the presence of $6 \mathrm{M}$ urea solution containing $12 \mathrm{~mm} 2$-mercaptoethanol. Protein concentration was determined by the method of Lowry.

\section{Labelling of Ribosomal Proteins}

Ribosomal proteins were labelled with ${ }^{3} \mathrm{H}$ - or ${ }^{14} \mathrm{C}$-lysine, principally following the method of Iтон, Отака and Osawa ${ }^{26,27)}$. Cells of E. coli NIHJ were grown aerobically for 4 hours at $37^{\circ} \mathrm{C}$ in Tris- $\mathrm{NaCl}(0.5 \%)$-glucose $(0.3 \%)$ medium supplemented with $10 \mu \mathrm{c} / \mathrm{ml}$ of ${ }^{3} \mathrm{H}$-lysine or $1 \mu \mathrm{c} / \mathrm{ml}$ of ${ }^{14} \mathrm{C}-$ lysine, $50 \mu \mathrm{g} / \mathrm{ml}$ of $\mathrm{L}$-methionine, and $20 \mu \mathrm{g} / \mathrm{ml}$ of each of other amino acids, and $300 \mu \mathrm{g} / \mathrm{ml}$ of yeast extract. Isotopically labelled $30 \mathrm{~S}$ or $50 \mathrm{~S}$ ribosomal proteins were prepared by the method described above.

In order to detect the alteration of ribosomal constituents, samples of $30 \mathrm{~S}$ or $50 \mathrm{~S}$ ribosomal proteins from ${ }^{3} \mathrm{H}$-lysine-labelled sensitive cells and from ${ }^{14} \mathrm{C}$-lysine-labelled resistant cells were mixed and simultaneously co-chromatographed on a CMC column. The radioactivity to each fraction was determined by a Packard liquid scintillation counter.

Reconstitution of Ribosomes from Ribosomal Proteins

Fractionated $\mathrm{P} 10$ protein and the other ribosomal proteins from parent strain and resistant mutant were combined as described in Tables 5 and 6 ; and then after adding $16 \mathrm{~S}$ ribosomal RNA from the parent strain (weight ratio of ribosomal proteins/RNA=3), the mixture was dialysed against buffer solution containing $20 \mathrm{mM} \mathrm{Mg}$ acetate and $12 \mathrm{mM}$ 2 -mercaptoethanol. The reconstituted $30 \mathrm{~S}$ subunits were recovered by sucrose density gradient centrifugation. The $70 \mathrm{~S}$ ribosomes were obtained by adding $50 \mathrm{~S}$ subunits from the parent strain to the reconstituted $30 \mathrm{~S}$ subunits $(50 \mathrm{~S} / 30 \mathrm{~S}=2)$ and by dialysis and centrifugation.

\section{Results}

Effects of the Antibiotics on Reconstituted Ribosomes with $30 \mathrm{~S}$ and $50 \mathrm{~S}$ Subunits, and with $23 \mathrm{~S}$ Core, SP 30 and $50 \mathrm{~S}$

Subunits Derived from Parent Strain and Resistant Mutant

The $30 \mathrm{~S}$ and $50 \mathrm{~S}$ subunits from the parent strain and the KM-resistant mutant were reassociated in various combinations, and the poly U-directed incorporation of phenylalanine was assayed in the presence and absence of KM.

The incorporation of isoleucine by KM-induced miscoding in the presence of poly $\mathrm{U}$ was also examined. KM inhibited polyphenylalanine synthesis definitely when the ribosomes contained $30 \mathrm{~S}$ subunits derived from the parent strain, but much less when these subunits were derived from the resistant mutant. Whether $50 \mathrm{~S}$ subunits of the reassociated ribosomes were derived from parent strain or the resistant mutant did 
not influence the inhibition by KM. Moreover, the poly U-directed incorporation of isoleucine in the presence of KM was more markedly stimulated with the ribosomes containing $30 \mathrm{~S}$ derived from the parent strain. These results show that the determinant of sensitivity to KM exists in $30 \mathrm{~S}$ subunits, but not in $50 \mathrm{~S}$ subunits.

The $23 \mathrm{~S}$ core and SP 30 were prepared from the two strains respectively, and $30 \mathrm{~S}$ subunits were reconstituted in different combinations. Not only inhibition of poly-

Table 1. Poly U-directed incorporation of phenylalanine and isoleucine by reconstituted ribosomes from $E$. coli NIHJ strain and the KM-resistant mutant.

\begin{tabular}{|c|c|c|c|c|c|c|c|c|c|c|c|}
\hline \multicolumn{4}{|c|}{ Ribosomal subunits } & \multicolumn{5}{|c|}{ Phenylalanine incorporated } & \multicolumn{3}{|c|}{ Isoleucine incorporated } \\
\hline $50 \mathrm{~S}$ & $30 \mathrm{~S}$ & $23 \mathrm{~S}$ & SP30 & Control & $\mathrm{KM}$ & $\begin{array}{l}\% \\
\text { Inhibition) }\end{array}$ & $\mathrm{SM}$ & $\begin{array}{l}\% \\
\text { Inhibition) }\end{array}$ & Control & $\mathrm{KM} \quad(\%$ & Stimulation) \\
\hline S & S & & & 60.7 & 35.2 & $(42)$ & 39.5 & $(35)$ & 1. 42 & 10.81 & $(762)$ \\
\hline S & $\mathrm{R}$ & & & 58.0 & 56.7 & $(2)$ & 56.9 & $(2)$ & 1. 60 & 4.93 & $(308)$ \\
\hline $\mathrm{R}$ & S & & & 52.2 & 31.3 & $(40)$ & 37.6 & $(28)$ & 1. 22 & 7.69 & $(629)$ \\
\hline $\mathrm{R}$ & $\mathrm{R}$ & & & 54.9 & 52.6 & (4) & 51.6 & ( 6$)$ & 0.97 & 2.75 & $(284)$ \\
\hline$S$ & & $\mathrm{~S}$ & $S$ & 47.2 & 28.3 & $(40)$ & 32.6 & $(31)$ & 1.65 & 8.50 & $(515)$ \\
\hline S & & $S$ & $\mathrm{R}$ & 50.0 & 30.5 & (39) & 36.5 & (27) & 1. 33 & 5. 59 & $(420)$ \\
\hline$S$ & & $\mathrm{R}$ & $S$ & 45.6 & 44.8 & ( 2) & 46.1 & - & 1. 36 & 3.07 & $(226)$ \\
\hline$S$ & & $\mathrm{R}$ & $\mathrm{R}$ & 44.5 & 45. 2 & - & 42.6 & (4) & 1. 54 & 2. 46 & $(160)$ \\
\hline $\mathrm{R}$ & & $S$ & $S$ & 40.1 & 26.0 & (35) & 26.9 & (33) & 1. 08 & 4.26 & (394) \\
\hline $\mathrm{R}$ & & $S$ & $\mathrm{R}$ & 42.3 & 25.8 & (39) & 29.6 & (30) & 1. 59 & 6.88 & $(432)$ \\
\hline $\mathrm{R}$ & & $\mathrm{R}$ & $S$ & 38.0 & 36.8 & ( 3$)$ & 35.3 & $(7)$ & 0.86 & 1.79 & (208) \\
\hline $\mathrm{R}$ & & $\mathrm{R}$ & $\mathrm{R}$ & 36.8 & 34.8 & (6) & 33.1 & (10) & 1. 24 & 2. 32 & (187) \\
\hline
\end{tabular}

The number represents $\mu \mu$ moles incorporated per $\mathrm{mg}$ of protein.

$\mathrm{S}$ : sensitive strain, $\mathrm{R}$ : resistant mutant, SP30 : split proteins of $30 \mathrm{~S}$ ribosomes, KM: kanamycin $2 \times 10^{-5} \mathrm{M}$ $\mathrm{SM}$ : streptomycin $2 \times 10^{-5} \mathrm{M}$.

Assay for incorporation was performed following the method of NIRENBERG and MATTHAEI ${ }^{29)}$. The reaction mixture contained, in a volume of $0.50 \mathrm{ml}, 50 \mathrm{~S} 230 \mu \mathrm{g}, 30 \mathrm{~S} 120 \mu \mathrm{g}, 23 \mathrm{~S}$ core $90 \mu \mathrm{g}, \mathrm{SP} 3080 \mu \mathrm{g}, 105,000 \times \mathrm{g}$ supernatant $150 \mu \mathrm{g}$, sRNA $150 \mu \mathrm{g}$, poly U $20 \mu \mathrm{g}$, ATP $1 \mu$ mole, GTP $0.05 \mu$ mole, creatine phosphate $2 \mu \mathrm{moles}$, creatine phosphokinase [EC 2.7.3.2] $50 \mu \mathrm{g},{ }^{14} \mathrm{C}$-phenylalanine or ${ }^{14} \mathrm{C}$-isoleucine $0.1 \mu \mathrm{c}$, and kanamycin or streptomycin $0.01 \mu$ mole. The buffer solution used consisted of $\mathrm{Mg}$ acetate $10 \mathrm{~mm}, \mathrm{NH}_{4} \mathrm{Cl} 50 \mathrm{~mm}, 2-\mathrm{mercaptoethanol} 6 \mathrm{~mm}$, and Tris- $\mathrm{HCl} 10 \mathrm{~mm}$, pH 7.6.

It was incubated at $37^{\circ} \mathrm{C}$ for 30 minutes. The radioactivity of hot TCA-insoluble fraction was determined by a windowless gas flow counter, and protein content by the method of LowRY.

Table 2. Poly U-directed incorporation of phenylalanine and isoleucine by reconstituted ribosomes from $E$. coli NIHJ strain and the SM-resistant mutant.

\begin{tabular}{|c|c|c|c|c|c|c|c|c|c|c|c|}
\hline \multicolumn{4}{|c|}{ Ribosomal subunits } & \multicolumn{5}{|c|}{ Phenylalanine incorporated } & \multicolumn{3}{|c|}{ Isoleucine incorporated } \\
\hline $50 \mathrm{~S}$ & $30 \mathrm{~S}$ & $23 \mathrm{~S}$ & SP30 & Control & $\mathrm{SM}$ & $\begin{array}{l}\text { (\% } \\
\text { Inhibition) }\end{array}$ & $\mathrm{KM}$ & $\begin{array}{l}(\% \\
\text { Inhibition) }\end{array}$ & Control & SM $(\%$ & Stimulation) \\
\hline $\mathrm{S}$ & S & & & 57.2 & 38.9 & $(32)$ & 34.3 & $(40)$ & 0.89 & 6.13 & $(689)$ \\
\hline$S$ & $\mathrm{R}$ & & & 46.4 & 44.8 & (4) & 42.2 & (9) & 0.77 & 2.08 & $(270)$ \\
\hline $\mathrm{R}$ & S & & & 43.0 & 30.1 & $(30)$ & 25.4 & $(41)$ & 0.72 & 4. 62 & $(642)$ \\
\hline $\mathrm{R}$ & $\mathrm{R}$ & & & 39.5 & 38.9 & $(2)$ & 35.2 & $(11)$ & 0.68 & 1.75 & $(258)$ \\
\hline S & & S & $\mathrm{S}$ & 40.3 & 28.6 & $(29)$ & 25.8 & $(36)$ & 0.65 & 2.76 & (425) \\
\hline S & & S & $\mathrm{R}$ & 36.7 & 25.3 & (31) & 22.8 & (38) & 0.66 & 2.30 & $(348)$ \\
\hline$S$ & & $\mathrm{R}$ & $S$ & 38.9 & 37.0 & (5) & 35.8 & ( 8 ) & 0.58 & 0.97 & (167) \\
\hline$S$ & & $\mathrm{R}$ & $\mathrm{R}$ & 35.6 & 34.4 & ( 3$)$ & 34.2 & (4) & 0.55 & 0.66 & (120) \\
\hline $\mathrm{R}$ & & S & $S$ & 30.8 & 22.1 & (28) & 19.4 & (37) & 0.61 & 1.74 & $(285)$ \\
\hline $\mathrm{R}$ & & $S$ & $\mathrm{R}$ & 31.4 & 22.6 & (28) & 20.7 & (34) & 0.63 & 1. 58 & $(250)$ \\
\hline $\mathrm{R}$ & & $\mathrm{R}$ & S & 27.5 & 26.6 & (3) & 24.8 & (10) & 0.59 & 0.62 & (105) \\
\hline $\mathrm{R}$ & & $\mathrm{R}$ & $\mathrm{R}$ & 28.0 & 25.7 & ( 8 ) & 25.8 & ( 8$)$ & 0.58 & 0.74 & (128) \\
\hline
\end{tabular}

The reaction mixture and the assay conditions were the same as in Table 1. 
peptide synthesis by KM, but also miscoding induced by $\mathrm{KM}$ was more markedly observed when the $23 \mathrm{~S}$ core of sensitive $30 \mathrm{~S}$ subunits was uesd. SP 30 did not affect the sensitivity to KM, irrespective of its origin. It can be concluded that the sensitivity to $\mathrm{KM}$ resides in $23 \mathrm{~S}$ core of $30 \mathrm{~S}$ subunits. The results are summarized in Table 1.

The same experiments were carried out as to the sensitivity to SM, using SMresistant mutant. The results presented in Table 2 were quite similar to those on sensitivity to KM. Reassociated ribosomes derived from the KM-resistant mutant were resistant to SM (Table 1); similarly those derived from the SM-resistant mutant were resistant to $\mathrm{KM}$ (Table 2).

Effects of Antibiotics on the Reconstituted Ribosomes with

\section{further Fractionated Components}

The $16 \mathrm{~S}$ ribosomal RNA, CP 30 and SP 30 prepared from $30 \mathrm{~S}$ subunits of parent strain and resistant mutant were mixed in different combinations, and the mixtures

Table 3. Poly U-directed incorporation of phenylalanine and isoleucine by reconstituted ribosomes, using 16S ribosomal RNA, CP30 and SP30 from $E$. coli NIHJ strain and the KM-resistant mutant.

\begin{tabular}{|c|c|c|c|c|c|c|c|c|c|c|}
\hline \multicolumn{3}{|c|}{ Ribosomal subunits } & \multicolumn{5}{|c|}{ Phenylalanine incorporated } & \multicolumn{3}{|c|}{ Iosleucine incorporated } \\
\hline 16S RNA & CP30 & SP30 & Control & $\mathrm{KM}$ & $\begin{array}{l}(\% \\
\text { Inhibition) }\end{array}$ & $\mathrm{SM}$ & $\begin{array}{l}(\% \\
\text { Inhibition) }\end{array}$ & Control & $\mathrm{KM}(\%$ & Stimulation) \\
\hline $\mathrm{S}$ & $\mathrm{S}$ & $S$ & 44.9 & 26.9 & (40) & 31.0 & $(31)$ & 1.14 & 6.43 & $(564)$ \\
\hline$S$ & $\mathrm{~S}$ & $\mathrm{R}$ & 41.7 & 26.2 & $(37)$ & 27.9 & $(33)$ & 1. 01 & 4.73 & $(468)$ \\
\hline $\mathrm{S}$ & $\mathrm{R}$ & $S$ & 42.3 & 37.7 & (11) & 38.9 & ( 8 ) & 0.95 & 2.09 & $(220)$ \\
\hline $\mathrm{S}$ & $\mathrm{R}$ & $\mathrm{R}$ & 40.0 & 37.2 & ( 7$)$ & 35.2 & $(12)$ & 1.08 & 1.89 & $(179)$ \\
\hline $\mathrm{R}$ & $S$ & $S$ & 42.5 & 27.2 & (36) & 31.0 & (27) & 1. 21 & 5.38 & $(447)$ \\
\hline $\mathrm{R}$ & $S$ & $\mathrm{R}$ & 43.5 & 28.3 & (35) & 32.6 & (25) & 0.95 & 3.67 & $(386)$ \\
\hline $\mathrm{R}$ & $\mathrm{R}$ & $S$ & 39.1 & 41.2 & - & 37.1 & (5) & 0.89 & 1. 39 & (157) \\
\hline $\mathrm{R}$ & $\mathrm{R}$ & $\mathrm{R}$ & 39.4 & 37.0 & (6) & 38.2 & ( 3 ) & 0.83 & 1. 14 & (138) \\
\hline
\end{tabular}

The number represents $\mu \mu$ moles incorporated per $\mathrm{mg}$ of protein.

$S$ : sensitive strain, $R$ : resistant mutant, KM: kanamycin $2 \times 10^{-5} \mathrm{M}, \mathrm{SM}:$ streptomycin $2 \times 10^{-5} \mathrm{M}$.

The reaction mixture, $0.50 \mathrm{ml}$, contained $50 \mathrm{~S}$ from parent strain $280 \mu \mathrm{g}$, SP30 $85 \mu \mathrm{g}, 16 \mathrm{~S}$ ribosomal RNA plus CP30 $150 \mu \mathrm{g}, 105,000 \times \mathrm{g}$ supernatant $150 \mu \mathrm{g}$, sRNA $170 \mu \mathrm{g}$, poly U $20 \mu \mathrm{g}$, ATP $1 \mu$ mole, GTP $0.05 \mu$ mole, creatine phsphate $2 \mu$ moles, creatine phosphokinase [EC 2.7.3.2] $50 \mu \mathrm{g},{ }^{14} \mathrm{C}$-phenylalanine or ${ }^{14} \mathrm{C}$-isoleucine $0.1 \mu \mathrm{c}$, and kanamycin or streptomycin $0.01 \mu$ mole.

The incorporation was assayed as described in Table 1.

Table 4. Poly U-directed incorporation of phenylalanine and isoleucine by reconstituted ribosomes, using $16 \mathrm{~S}$ ribosomal RNA, CP30 and SP30 from $E$. coli NIHJ strain and the SM-resistant mutant.

\begin{tabular}{c|c|c|c|cc|cc|c|c|c}
\hline \multicolumn{2}{c|}{ Ribosomal subunits } & \multicolumn{5}{c|}{ Phenylalanine incorporated } & \multicolumn{3}{|c}{ Isoleucine incorporated } \\
\hline 16S RNA & CP30 & SP30 & Control & SM & $\begin{array}{c}\text { \% } \\
\text { Inhibition) }\end{array}$ & KM & $\begin{array}{c}\text { \% } \\
\text { Inhibition) }\end{array}$ & Control & SM & (\% Stimulation) \\
\hline S & S & S & 31.8 & 22.2 & $(30)$ & 20.0 & $(37)$ & 0.65 & 2.08 & $(320)$ \\
S & S & R & 28.4 & 20.4 & $(28)$ & 16.8 & $(41)$ & 0.71 & 2.18 & $(307)$ \\
S & R & S & 25.0 & 22.8 & $(9)$ & 22.5 & $(10)$ & 0.68 & 0.76 & $(112)$ \\
S & R & R & 25.3 & 24.2 & $(4)$ & 23.3 & $(8)$ & 0.62 & 0.59 & $(95)$ \\
R & S & S & 21.5 & 16.1 & $(25)$ & 14.2 & $(34)$ & 0.70 & 1.64 & $(234)$ \\
R & S & R & 18.2 & 12.9 & $(29)$ & 12.0 & $(34)$ & 0.65 & 1.67 & $(257)$ \\
R & R & S & 20.1 & 18.9 & $(6)$ & 17.9 & $(11)$ & 0.58 & 0.63 & $(109)$ \\
R & R & R & 19.8 & 19.2 & $(3)$ & 18.4 & $(7)$ & 0.56 & 0.63 & $(112)$ \\
\hline
\end{tabular}


were dialysed against a buffer solution containing $10 \mathrm{~mm} \mathrm{Mg}$ acetate. The reconstituted $30 \mathrm{~S}$ particles were recovered by centrifugation. The $50 \mathrm{~S}$ subunits derived from the parent strain were added to obtain $70 \mathrm{~S}$ ribosomes, whose sensitivities to $\mathrm{KM}$ and SM were investigated.

$\mathrm{KM}$ and SM inhibited in a similar degree the poly U-directed incorporation of phenylalanine, and also stimulated markedly the incorporation of isoleucine when the reconstituted $30 \mathrm{~S}$ subunits were composed of CP 30 derived from the parent strain. But the two antibiotics did not inhibit the poly U-directed incorporation of phenyl-

Fig. 1. Co-chromatography on carboxymethyl-cellulose (CMC) columns of labelled ribosomal proteins from parent strain and KM-resistant mutant

: ${ }^{3} \mathrm{H}-1$ sine-labelled protein of parent strain

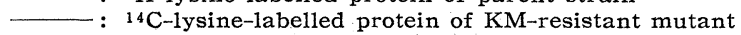

Sample of about $8 \mathrm{mg}$ was placed on a CMC column (size $0.8 \times 60 \mathrm{~cm}$ ). Proteins were eluted from the column with a linear sodium acetate gradient $(0.05 \sim 0.5 \mathrm{M})$. The flow rate was 1.5 $\mathrm{ml}$ per 12 minutes.

To measure the double-labelled radioactivity in proteins, carrier of serum albumin was added to each fraction; and the radioactivity of the cold TCA-insoluble fraction was determined by a Packard liquid scintillation counter.

(a) $30 \mathrm{~S}$ protein

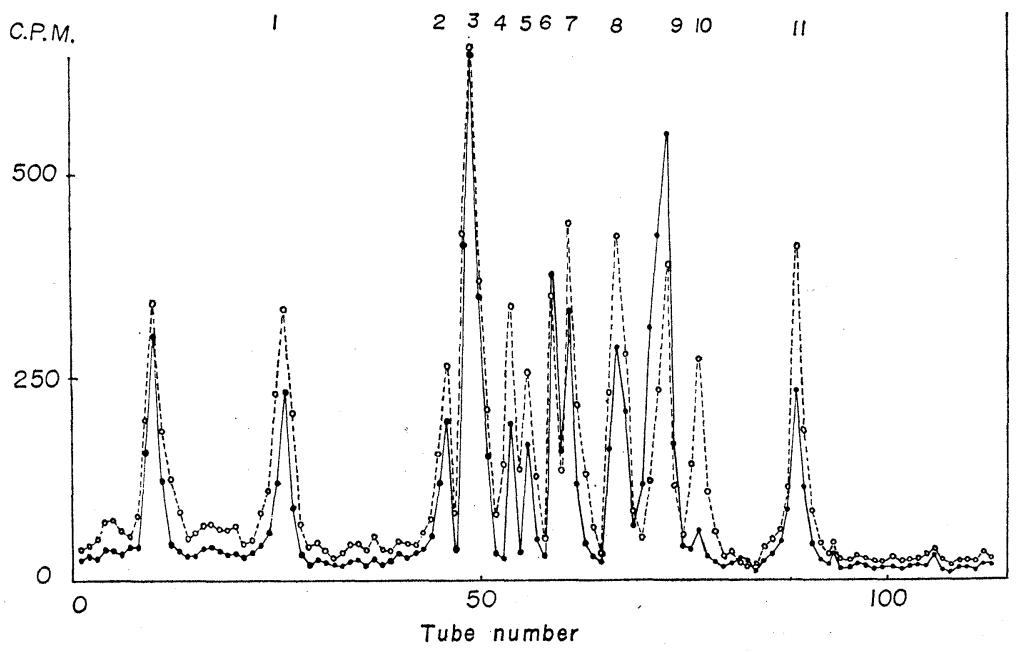

(b) $50 \mathrm{~S}$ protein

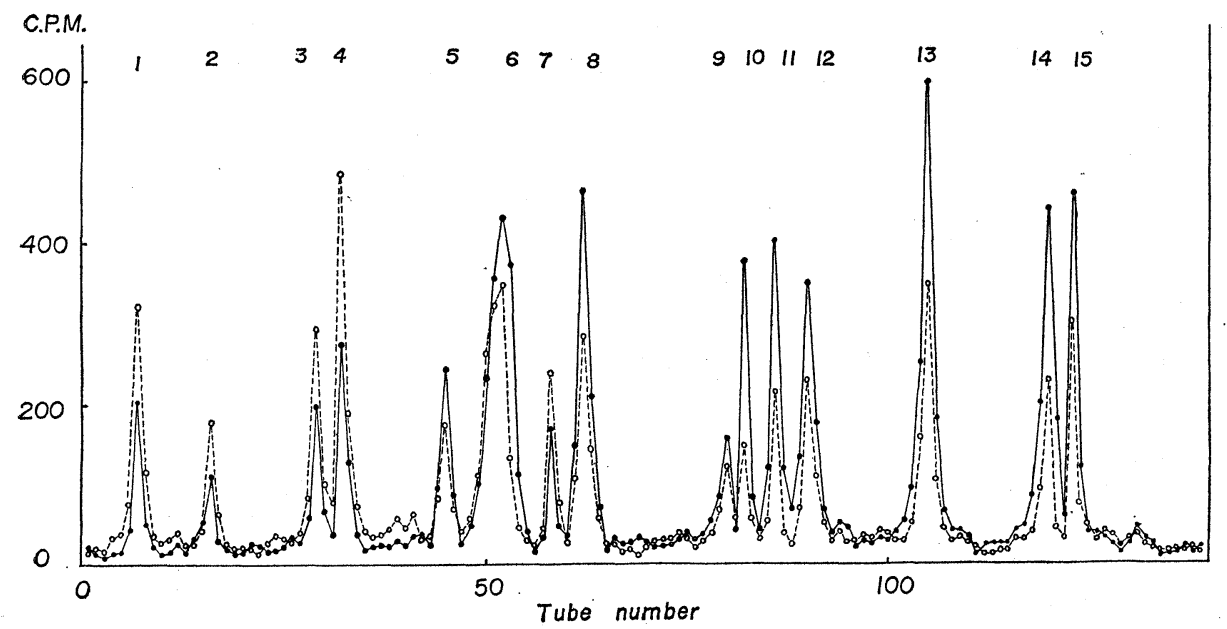


Fig. 2. Co-chromatography on CMC columns of labelled ribosomal proteins from parent strain and SM-resistant mutant

- ${ }^{3} \mathrm{H}-1 y$ sine-labelled protein of parent strain : ${ }^{14} \mathrm{C}$-lysine-labelled protein of SM-resistant mutant

(a) $30 \mathrm{~S}$ protein
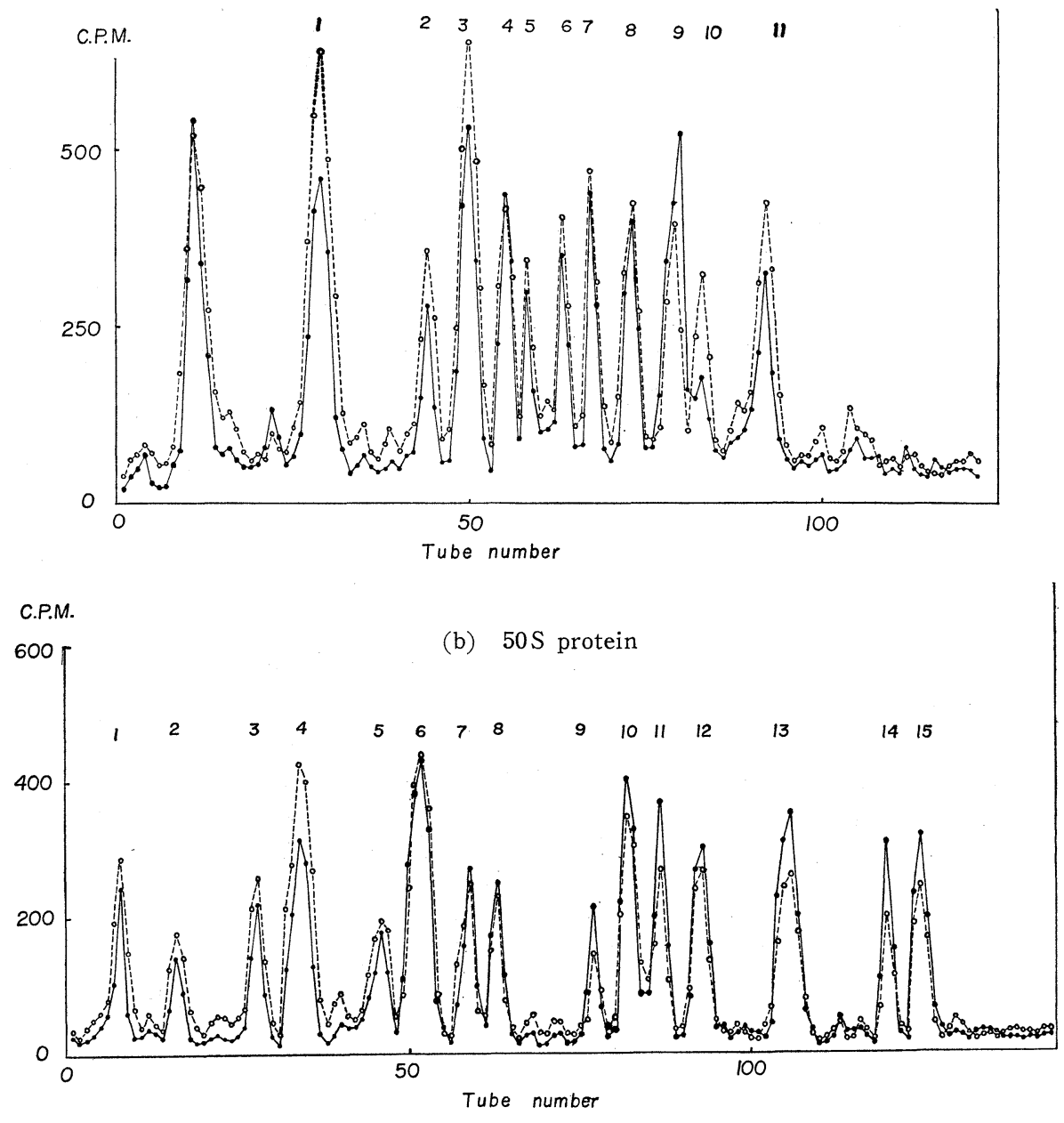

alanine, nor stimulate the incorporation of isoleucine, when the system contained the CP 30 derived from the mutant resistant to the corresponding antibiotic. The results. are shown in Tables 3 and 4 .

The origin of SP 30 and $16 \mathrm{~S}$ ribosomal RNA, in contrast, did not affect the sensitivity of the reconstituted $30 \mathrm{~S}$ subunits.

The present investigation indicates that the alteration which causes KM resistance and SM resistance is in CP 30 of the mutants.

Difference in Ribosomal Proteins between Parent Strain and Resistant Mutant

The $30 \mathrm{~S}$ or $50 \mathrm{~S}$ ribosomal proteins of parent strain were labelled with ${ }^{3} \mathrm{H}$-lysine, and those of $\mathrm{KM}$-resistant mutant were labelled with ${ }^{14} \mathrm{C}-$-lysine, as described in "Method". The dissociated $30 \mathrm{~S}$ ribosomal proteins from the two origins, were mixed and chromatographed with a CMC column to detect any difference in the proteins of the parent strain and the resistant mutant. As shown in Fig. 1 a, the peak 9 of 
Fig. 3. Chromatography of $30 \mathrm{~S}$ ribosomal proteins from parent strain and those from KM-resistant mutant

(a) and (b): Sample of about $180 \mathrm{mg}$ was applied on a CMC column (size $1.9 \times 95 \mathrm{~cm}$ ). Proteins were eluted from the column with a linear sodium acetate gradient $(0.05 \sim 0.5 \mathrm{M})$. The flow rate was $1.5 \mathrm{ml}$ per 15 minutes. Protein content was determined by the method of LowRy.

(c) : Fractions containing No. 9 and No. 10 components from KM-resistant mutant were pooled and applied to another column $(\operatorname{size} 1.9 \times 42 \mathrm{~cm})$. Elution was done with a linear sodium acetate gradient $(0.2 \sim 0.6 \mathrm{M})$.

(a) Proteins from parent strain

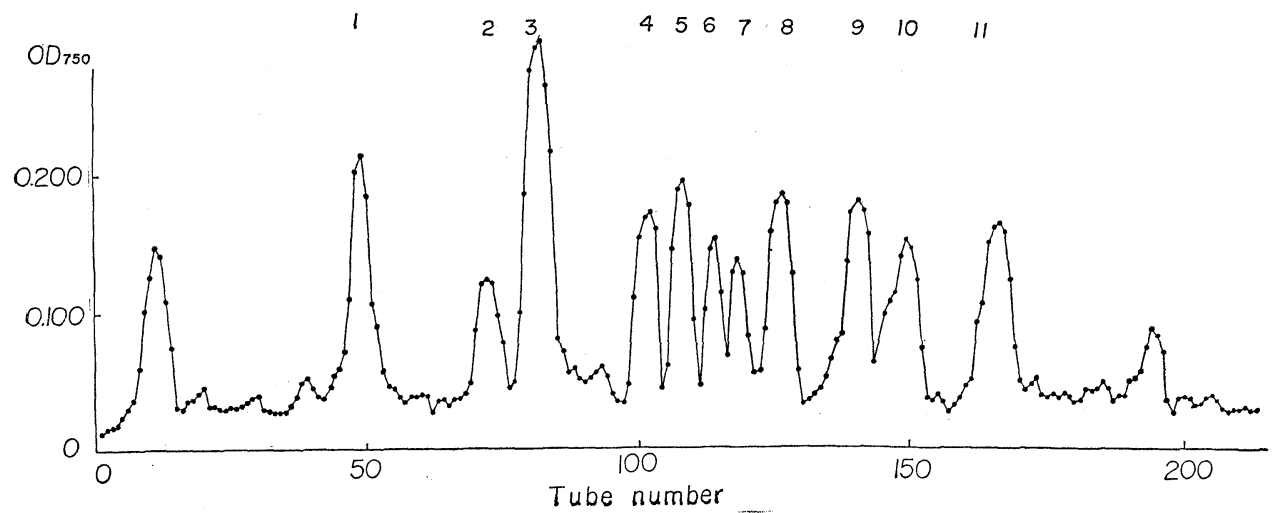

(b) Proteins from KM-resistant mutant

(c) Rechromatography of components from KM-resistant mutant

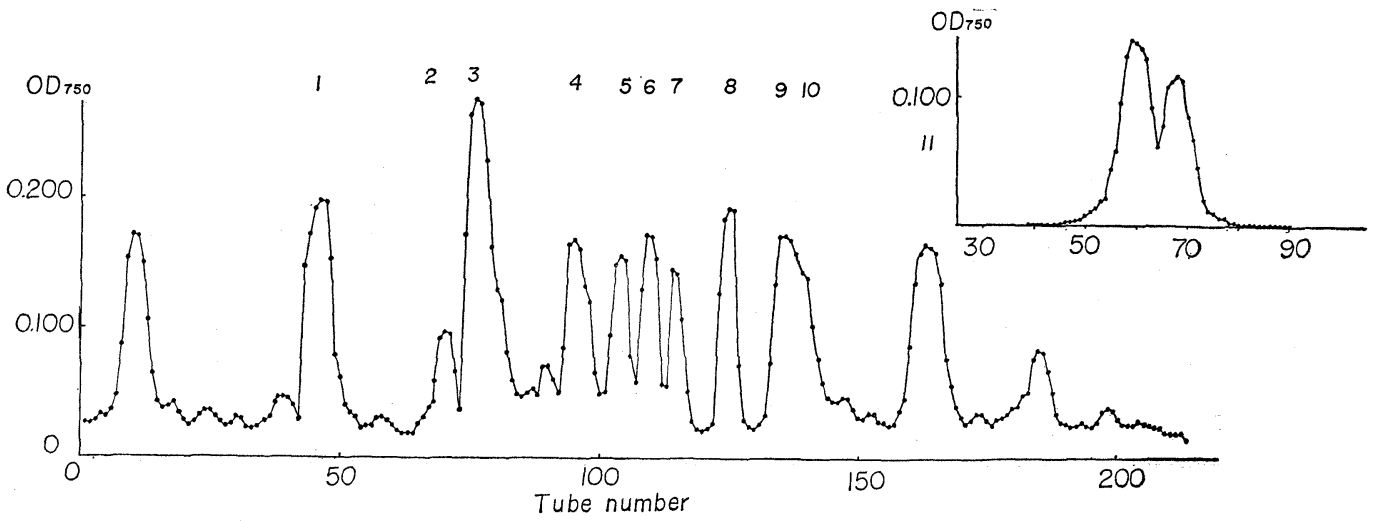

${ }^{14} \mathrm{C}-$-lysine was remarkably higher relative to the corresponding peak of ${ }^{3} \mathrm{H}$-lysine, and the peak 10 of ${ }^{14} \mathrm{C}-$-lysine was hardly detected. The other peaks of ${ }^{14} \mathrm{C}$ - and ${ }^{3} \mathrm{H}$-lysine were located at identical positions. The SM-resistant mutant resembled the KMresistant mutant (Fig. 2 a).

The fractionation of $50 \mathrm{~S}$ ribosomal proteins was performed in the same method as described above. No significant difference was observed between the parent strain and either mutant (Figs. $1 \mathrm{~b}, 2 \mathrm{~b}$ ).

When the fraction constituting peak 9 from either resistant $30 \mathrm{~S}$ subunit was rechromatographed with a GMC column, two peaks were separated from each other (Figs. $3 \mathrm{c}$ and $4 \mathrm{c}$ ). It thus appears that either mutation caused protein $\mathrm{P} 10$ to move more slowly on GMC.

Effects of Antibiotics on $30 \mathrm{~S}$ Subunits Reconstituted by Combining Protein P 10 and Complementary Ribosomal Proteins from Parent Strain and Resistant Mutant 
Fig. 4. Chromatography of $30 \mathrm{~S}$ ribosomal proteins from parent strain and those from SM-resistant mutant

The procedure was done as described in Fig. 3.

(a) Proteins from parent strain

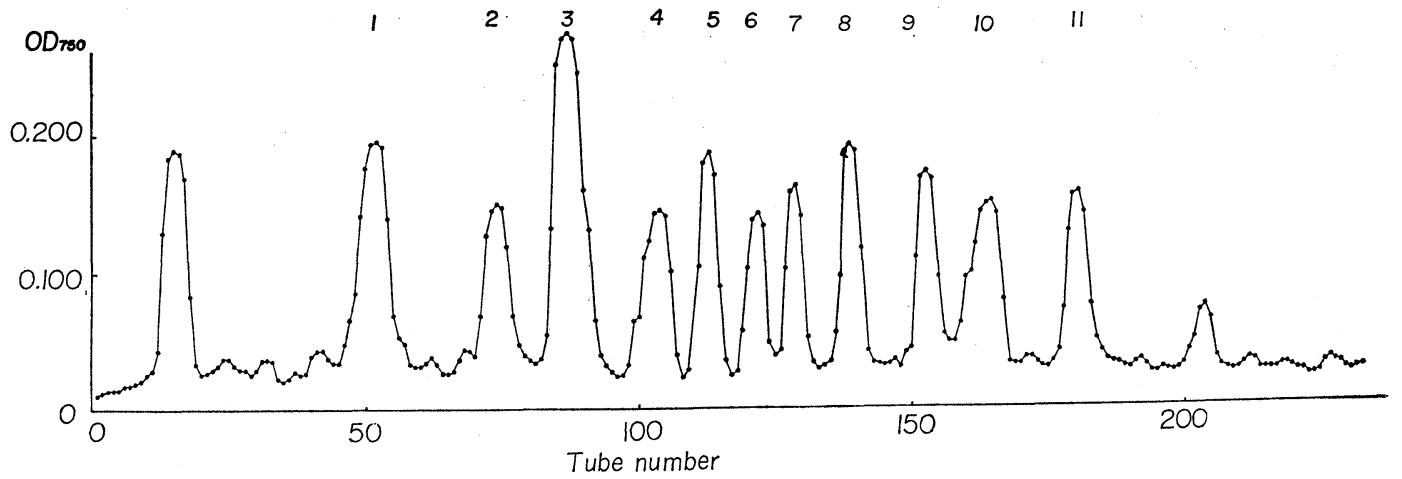

(b) Proteins from SM-resistant mutant

(c) Rechromatography of components from SM-resistant mutant

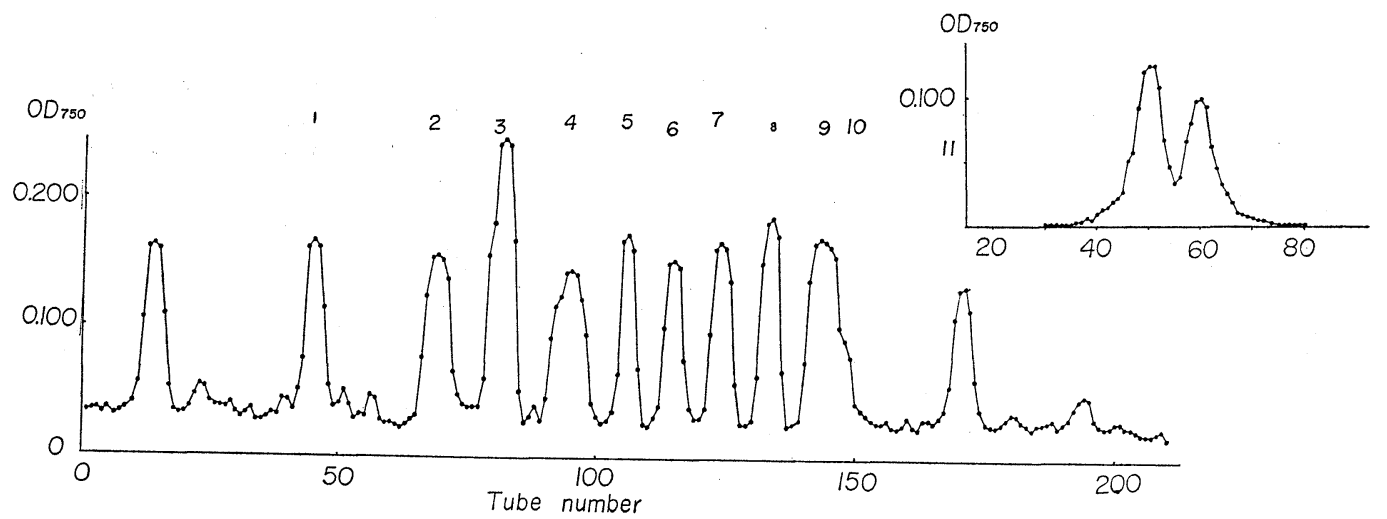

Table 5. Poly U-directed incorporation of phenylalanine and isoleucine by reconstituted ribosomes, using $30 \mathrm{~S}$ ribosomal proteins from $E$. coli NIHJ strain and the KM-resistant mutant.

\begin{tabular}{|c|c|c|c|c|c|c|c|c|c|c|}
\hline \multicolumn{2}{|c|}{$\begin{array}{l}\text { Ribosomal } \\
\text { proteins }\end{array}$} & \multicolumn{6}{|c|}{ Phenylalanine incorporated } & \multicolumn{3}{|c|}{ Isoleucine incorporated } \\
\hline$\sum \mathrm{Pi}-\mathrm{P} 10$ & P10 & Control & KM & (\% Inhibition) & SM & $(\%$ & Inhibition) & Control & $\mathrm{KM} \quad(\%$ & Stimulation) \\
\hline$S$ & $S$ & 10.24 & 6.34 & $(38)$ & 7.30 & & (29) & 0.25 & 1.85 & $(740)$ \\
\hline S & $\mathrm{R}$ & 9.07 & 8.34 & $(8)$ & 7.98 & & (12) & 0.21 & 0.44 & (209) \\
\hline$S$ & 一 & 2.70 & 2.54 & ( 6$)$ & 2.59 & & (4) & 0.18 & 0.75 & $(416)$ \\
\hline $\mathrm{R}$ & $S$ & 6. 88 & 5. 01 & $(27)$ & 5. 42 & & (21) & 0.17 & 0.79 & $(465)$ \\
\hline $\mathrm{R}$ & $\mathrm{R}$ & 6.02 & 5. 48 & (9) & 5.66 & & ( 6$)$ & 0.14 & 0.17 & (121) \\
\hline $\mathrm{R}$ & - & 2.24 & 2.19 & $(2)$ & 2.13 & & (5) & 0.10 & 0.24 & $(240)$ \\
\hline \multicolumn{2}{|c|}{$30 S(S)$} & 20.95 & 11.10 & (47) & 13.61 & & (35) & 0.62 & 7.24 & $(1,168)$ \\
\hline \multicolumn{2}{|c|}{$30 S(R)$} & 15.77 & 15.30 & ( 3$)$ & 14.95 & & (5) & 0.58 & 2.07 & (358) \\
\hline
\end{tabular}

The number represents $\mu \mu$ moles incorporated per mg of protein.

$\mathrm{S}$ : sensitive strain, $\mathrm{R}$ : resistant mutant, $\mathrm{KM}:$ kanamycin $2 \times 10^{-5} \mathrm{M}, \mathrm{SM}$ : streptomycin $2 \times 10^{-5} \mathrm{M}, \mathrm{P} 10:$ peak

10 ribosomal protein, $\Sigma \mathrm{Pi}-\mathrm{P} 10$ : all other proteins except $\mathrm{P} 10$.

The reaction mixture contained, in a volume of $0.50 \mathrm{ml}, 50 \mathrm{~S}$ from parent strain $200 \mu \mathrm{g}$, reconstituted $30 \mathrm{~S}$ subunit consisting of ribosomal proteins in different combination $105 \mu \mathrm{g}, 105,000 \times g$ supernatant $120 \mu \mathrm{g}$, sRNA $100 \mu \mathrm{g}$, poly U $20 \mu \mathrm{g}$, ATP $1 \mu$ mole, GTP $0.05 \mu$ mole, creatine phosphate $2 \mu$ moles, creatine phosphokinase $50 \mu \mathrm{g}$, ${ }^{14} \mathrm{C}$-phenylalanine or ${ }^{14} \mathrm{C}$-isoleucine $0.1 \mu \mathrm{c}$, and kanamycin or streptomycin $0.01 \mu$ mole.

The buffer solution used consisted of $\mathrm{Mg}$ acetate $10 \mathrm{~mm}, \mathrm{NH}_{4} \mathrm{Cl} 50 \mathrm{~mm}$, 2-mercaptoethanol $12 \mathrm{~mm}$, and Tris$\mathrm{HCl} 10 \mathrm{~mm}, \mathrm{pH} 7.6$. The incorporation was assayed as described in Table 1. 
Table 6. Poly U-directed incorporation of phenylalanine and isoleucine by reconstituted ribosomes, using $30 \mathrm{~S}$ ribosomal proteins from $E$. coli $\mathrm{NIHJ}$ strain and the SM-resistant mutant.

\begin{tabular}{|c|c|c|c|c|c|c|c|c|c|}
\hline \multicolumn{2}{|c|}{$\begin{array}{c}\text { Ribosomal } \\
\text { proteins }\end{array}$} & \multicolumn{5}{|c|}{ Phenylalanine incorporated } & \multicolumn{3}{|c|}{ Isoleucine incorporated } \\
\hline$\sum \mathrm{Pi}-\mathrm{P} 10$ & $\mathrm{P} 10$ & Control & $\mathrm{SM}$ & (\% Inhibition) & $\mathrm{KM} \quad(\%$ & Inhibition) & Control & $\mathrm{SM}(\%$ & Stimulation) \\
\hline$S$ & $S$ & 7.12 & 5.13 & (28) & 4.85 & (32) & 0.42 & 2.75 & (655) \\
\hline S & $\mathrm{R}$ & 6.64 & 5.98 & (10) & 5.58 & (16) & 0.38 & 0.82 & (216) \\
\hline S & - & 2.35 & 2.21 & (6) & 2.14 & $(9)$ & 0.28 & 1.04 & $(371)$ \\
\hline $\mathrm{R}$ & $S$ & 5.18 & 3.88 & (25) & 3. 72 & (28) & 0.18 & 0.99 & $(550)$ \\
\hline $\mathrm{R}$ & $\mathrm{R}$ & 6.03 & 5.85 & ( 3$)$ & 5.25 & (13) & 0.20 & 0.36 & $(180)$ \\
\hline $\mathrm{R}$ & - & 1.78 & 1.71 & (4) & 1.66 & ( 7$)$ & 0.16 & 0.41 & $(256)$ \\
\hline \multicolumn{2}{|c|}{$30 S(S)$} & 18.11 & 11.24 & (38) & 10.89 & $(40)$ & 0.83 & 8. 12 & $(980)$ \\
\hline \multicolumn{2}{|c|}{$30 \mathrm{~S}(\mathrm{R})$} & 13.89 & 13.20 & (5) & 12.21 & (12) & 0.62 & 2.23 & $(360)$ \\
\hline
\end{tabular}

The reaction mixture was simliar to that described in Table 5.

The $30 \mathrm{~S}$ ribosomal proteins from parent strain and KM- or SM-resistant mutant were fractionated by CMC column chromatography. The $30 \mathrm{~S}$ subunits were reconstituted, as described in "Methods", from P 10 and the other $30 \mathrm{~S}$ ribosomal proteins from the parent strain and resistant mutants in various combinations. The $16 \mathrm{~S}$ ribosomal RNA and $50 \mathrm{~S}$ subunits used were prepared from parent strain. As shown in Tables 5 and $6, \mathrm{KM}$ and $\mathrm{SM}$ inhibited the poly $\mathrm{U}$-directed incorporation of phenylalanine when the system contained protein P10 derived from the parent strain, but there was little inhibition when P10 was derived from the resistant mutant. The other $30 \mathrm{~S}$ ribosomal proteins did not significantly affect the inhibition by the antibiotics.

The stimulation of isoleucine incorporation with poly $U$ in the presence of $K M$ or SM was also dependent on the origin of $\mathrm{P} 10$ protein, but not on that of the other $30 \mathrm{~S}$ ribosomal proteins. Cross-resistance to the two antibiotics was also observed in this experiment.

\section{Discussion}

The alteration which led to $\mathrm{KM}$ and $\mathrm{SM}$ resistances was associated with $30 \mathrm{~S}$ ribosomal subunits, not with $50 \mathrm{~S}$ ribosomal subunits. Moreover, it was demonstrated that the alteration was in $23 \mathrm{~S}$ core of $30 \mathrm{~S}$ subunits, and the origin of SP 30 did not affect the sensitivities to KM and SM. These results are in accord with previous studies, ${ }^{7,982}$. The present studies further indicated that the determinant component for KM or SM sensitivity was protein $\mathrm{P} 10$ in the fractionated $30 \mathrm{~S}$ ribosomal proteins.

The sensitivity to $\mathrm{KM}$ and that to $\mathrm{SM}$ are determined by the same ribosomal protein. In addition, the protein from either KM-resistant cells or SM-resistant cells showed resistance to both antibiotics in the present investigation. This suggests that the site of action of $\mathrm{KM}$ and that of $\mathrm{SM}$ are identical, or are overlapped mutually on the ribosomes.

The KM- and SM-resistant mutants employed showed one-way cross-resistance to the antibiotics. Almost the same pattern of resistance was demonstrated at the level of in vitro polypeptide-synthesizing system, using $70 \mathrm{~S}$ ribosomes. However, the mutual crossresistance of SM and $\mathrm{KM}$ was observed with dissociated and reconstituted $30 \mathrm{~S}$ ribosomes. Although this discrepancy is inexplicable, it is possible that other ribosomal proteins as well as P10 or some other factors may participate in the resistance to the antibiotics.

Although $\mathrm{P} 10$ protein in the fractionated ribosomal proteins appeared to be a single 
protein, it remains to be determined. The $\mathrm{P} 10$ protein from parent strain and that from resistant mutant exhibited a different behavior on CMC column chromatography, suggesting a change in charge and therefore in the amino acid components.

\section{Acknowledgement}

Grateful acknowledgement is made to Prof. N. Tanaka and Dr. T. Kinoshita for guidance and encouragement.

\section{Reference}

1) Spotts, C. R. \& R. T. Stanier : Mechanism of streptomycin action on bacteria : a unitary hypothesis. Nature $192: 633 \sim 637,1961$

2) Tanaka, N.; K. Sashikata, T. Nishimura \& H. Umezawa : Activity of ribosomes from kanamycin-resistant E. coli. Biochem. Biophys. Res. Commun. $16: 216 \sim 220,1964$

3) Syeyer, J. F.; P. Lengyel \& C. Basilio: Ribosomal localization of streptomycin sensitivity. Proc. Natl. Acad. Sci. U. S. $48: 684 \sim 686,1962$

4) Flaks, J. G.; E. C. Cox, M. L. Witting \& J. R. White: Polypeptide synthesis with ribosomes from streptomycin-resistant and dependent Escherichia coli. Biochem. Biophys. Res. Commun. $7: 390 \sim 393,1962$

5) Davies, J. E. : Studies on the ribosomes of streptomycin-sensitive and resistant strains of Escherichia coli. Proc. Natl. Acad. Sci. U. S. $51: 659 \sim 664,1964$

6) Cox, E. C.; J. R. White \& J. G. Flaks : Streptomycin action and the ribosome. Proc. Natl. Acad. Sci. U. S. $51: 703 \sim 709,1964$

7) Staehelin, T. \& M. Meselson : Determination of streptomycin sensitivity by a subunit of the $30 \mathrm{~S}$ ribosome of Escherichia coli. J. Mol. Biol. $19: 207 \sim 210,1966$

8) Traub, P.; K. Hosokawa \& M. Nomura : Streptomycin sensitivity and the structural components of the $30 \mathrm{~S}$ ribosomes of Escherichia coli. J. Mol. Biol. $19: 211 \sim 214,1966$

9) Traub, P.; K. Hosokawa \& M. Nomura: Physical and functional heterogeneity of ribosomal proteins. J. Mol. Biol. $19: 215 \sim 218,1966$

10) Traub, P. \& M. Nomura : Streptomycin resistance mutation in Escherichia coli: Altered ribosomal protein. Science $160: 198 \sim 199,1968$

11) Ozaki, M.; S. Mizushima \& M. Nomura : Identification and functional characterization of the protein controlled by the streptomycin-resistant locus in E. coli. Nature $222: 333 \sim 339,1969$

12) Davies, J.; L. Gorini \& B. D. Davis : Misreading of RNA codewords induced by aminoglycoside antibiotics. Mol. Pharmacol. $1: 93 \sim 106,1965$

13) MoCarthy, B. J. \& J. J. Holland: Denatured DNA as a direct template for in vitro protein synthesis. Proc. Natl. Acad. Sci. U. S. $54: 880 \sim 886,1965$

14) Masukawa, H. \& N. Tanaka: Stimulation by aminoglycosidic antibiotics of DNA-directed protein synthesis. J. Biochem. $62: 202 \sim 209,1967$

15) Tanaka, N.; Y. Yoshida, K. Sashikata, H. Yamaguchi \& H. Umezawa : Inhibition of polypeptide synthesis by kasugamycin, an aminoglycosidic antibiotic. J. Antibiotics, Ser. A 19:65 68, 1966

16) Davies, J.; P. Anderson \& B. D. Davis : Inhibition of protein synthesis by spectinomycin. Science $149: 1096 \sim 1098,1965$

17) Likover, T. E. \& C. G. Kurland : The contribution of DNA to translation errors induced by streptomycin in vitro. Proc. Natl. Acad. Sci. U. S. $58: 2385 \sim 2392,1967$

18) TaNaka, N.; H. Masukawa \& H. UmezaWA: Structural basis of kanamycin for miscoding activity. Biochem. Biophys. Res. Commun. $26: 544 \sim 549,1967$

19) Masukawa, H. \& N. Tanaka : Miscoding activity of amino sugars. J. Antibiotics $21: 70 \sim 72$, 1968

20) Moriкuво, Y. : Bacteriological studies on kanamycin. I. Antibacterial spectrum and one-way cross resistance of E. coli with streptomycin. J. Antibiotics, Ser. A $11: 171 \sim 180,1958$

Morikubo, Y. : Bacteriological studies on kanamycin. III. The cross resistance relation between kanamycin and dihydrostreptomycin in Mycobacterium 607. J. Antibiotics, Ser. A 12:90 97, 1959 
21) Tanaka, N.; K. Sashikata \& H. Umezawa : Antibiotic-sensitivity of ribosomes from kanamycinresistant E. coli. J. Antibiotics, Ser. A $20: 115 \sim 119,1967$

22) von Ehrenstein, G. \& F. Lipmann : Experiments on hemoglobin biosynthesis. Proc. Natl. Acad. Sci. U. S. $47: 941 \sim 950,1961$

23) Hosokawa, K.; R. K. Fujimura \& M. Nomura : Reconstitution of functionally active ribosomes from inactive subparticles and proteins. Proc. Natl. Acad. Sci. $55: 198 \sim 204,1966$

24) Staehelin, T. \& M. Meselson: In vitro recovery of ribosomes and of synthetic activity from synthetically inactive ribosomal subunits. J. Mol. Biol. $16: 245 \sim 249,1966$

25) Meselson, M.; M. Nomura, S. Brenner, C. Davern \& D. Schlessinger : Conservation of ribosomes during bacterial growth. J. Mol. Biol. $9: 696 \sim 711,1964$

26) Ітон, Т.; Е. Отака \& S. Osawa : Release of ribosomal proteins from Escherichia coli ribosomes with high concentrations of lithium chloride. J. Mol. Biol. $33: 109 \sim 122,1968$

27) Отака, E.; Т. Ітон \& S. Osawa: Ribosomal proteins of bacterial cells : strain- and speciesspecificity. J. Mol. Biol. $33: 93 \sim 107,1968$

28) Masukawa, H.; N. Tanaka \& H. Umezawa : Localization of kanamycin sensitivity in the $23 \mathrm{~S}$ core of $30 \mathrm{~S}$ ribosomes of E. coli. J. Antibiotics $21: 517 \sim 518,1968$

29) Nirenberg, M. W. \& J. H. Matthaei : The dependence of cell-free protein synthesis in $E$. coli upon naturally occurring or synthetic polyribonucleotides. Proc. Natl. Acad. Sci. U. S. 47 : 1588 1602, 1961 